\title{
Monetary and Fiscal Policies
}

\section{Shahid Kardar*}

\section{Abstract}

Though the Pakistani economy had recently achieved some level of macroeconomic stability, at present there are fears that this stability could be threatened. This paper looks at monetary and fiscal reforms over the last decade and focuses on the areas that need to be addressed on both fronts. In particular, the paper looks at how present monetary policy needs greater clarity and how fiscal policy needs to focus on raising public savings and diversifying the sources of borrowing.

\section{Introduction}

With inflation still hovering around 8\%-despite the monetary tightening over the last two years, a fiscal deficit threatening to cross $4.2 \%$ of GDP and the reversal of the current account surplus into a large deficit that could touch $5.5 \%$ of GDP, there are understandably fears that the macroeconomic stability achieved after a long and hard struggle, with a fair sprinkling of luck thrown in by the events of 9/11, has been lost. These macroeconomic imbalances are inducing pressures and new challenges for sustaining the present healthy rates of economic growth.

At a time when monetary policy was the easiest to handle, thanks to the surfeit of liquidity and the abundance of cheap money in the financial system (from donors in the form of aid and from overseas Pakistanis in the form of remittances), the State Bank did not perform its principal duty of controlling inflation with distinction. Inflation soared not simply because of the oil and food price inflation but largely because of a loose monetary policy $^{5}$. The State Bank allowed a huge increase in money supply, well above the rate justified by the expansion in the economy. Resultantly, Pakistan has the dubious distinction of having the highest inflation rate in this region; inflation has also been outpacing that of its trading partners and

\footnotetext{
* Former Finance Minister, Government of the Punjab.

${ }^{5}$ See Khan and Schimmelpfennig (2006) and Qayyum (2006).
} 
competitors. A good part of the problem of inflation has been fuelled by the consumption (private and public consumption) and investment boom of recent years, well beyond the production capacity of the economy (a gap of almost $4 \%$ of the GDP). The widening current account deficit is a classic sign of overheating and excessive demand build-up as domestic output fails to keep pace with surging demand facilitated by easier availability of credit, especially in the form of consumer financing.

The gap between government expenditures and its tax revenues continues to be close to 7 percentage points of the GDP, the differential that existed in 1999/2000 with the tax to GDP ratio actually worsening from $13 \%$ of GDP in the early 1990 s to under $11 \%$. That some of this gap is presently being filled by non-tax revenues which are expected to decline as the more profitable enterprises are privatized, cannot be a source of comfort for the future in terms of sustainability.

Another worrying feature is the growing savings-investment gap. This is presently being financed through remittances and non-secure sources of funding such as FDI (largely as privatization proceeds), external financing from Eurobonds, GDRs, donors and remittances, which also enabled the government to keep bank borrowings lower than what they might have been otherwise. Maintaining this large and widening gap will not be possible over a longer period.

The scope of this paper is, however, limited to an examination of monetary and fiscal polices to date and to propose a strategy for the future.

\section{Financial Sector and Monetary Policy Reforms}

The key measures that lay at the heart of the financial sector reforms initiated in the early 1990s included the enhancement of competitiveness in the banking sector through the privatization of financial institutions (FIs) and the easing of market entry of new Fls, improvements in their capital adequacy, reduction in the fragmentation of financial markets through the deregulation of interest rates on deposits and loans, a partial switch over to indirect marked-based instruments for monetary management ${ }^{6}$, the gradual dismantling of the system of directed and concessional credit schemes, facilitating the flotation of new securities through legal, policy and other procedural and regulatory reforms, strengthening the health of the banking

${ }^{6}$ The State Bank continues to buy government paper and use primary auctions for monetary management. 
system through Prudential Regulations (PRs), and by strengthening the capability of the SBP to fulfill its functional obligations.

In the realm of monetary policy the benefits of the financial sector reforms are visible in the development of a somewhat competitive money market for government paper (reflected in the dealers' market operating on narrow spreads between the bid and offer rates) ${ }^{7}$, and a well functioning secondary market for treasury bills, while the market for corporate debt, although thin, presently (owing to the lack of liquidity in the market and the time it takes to settle transactions) is beginning to show promise. Success has also been achieved in resource allocation by making lending based on sound economic and financial criteria, creating more developed money and capital markets that are mobilizing savings and making them available to the most efficient users, through appropriate incentive systems instead of discriminatory direct controls.

However, the bulk of the intermediary functions of the financial sector and the State Bank of Pakistan's monetary stabilization efforts are performed for the government or essentially dictated by the government's financing requirements. Even after the grant of autonomy to the State Bank, its principal activity has been to raise financing for the government. Since its monetary management is virtually driven by the borrowing needs of the government, $88 \%$ of its Net Domestic Assets (DNA) and 39\% of total assets comprise advances to the government. In fact, in FY06, the SBP claims on the government increased by more than total government borrowings from banks-the main factor behind the increase in reserve money. Similarly, the banks hold close to $40 \%$ of their assets in the form of cash with the SBP, government securities or advances to it for commodity financing. Add to it the savings in the National Savings Schemes (at Rs. 860 billion, 11\% of GDP) and we get an idea of the scale of the economy's financial savings mopped up by the government

Moreover, the direct financing arrangements between the GoP and the SBP, whereby there is an automatic replenishment of the Government's account with the SBP without any limit, by issuing treasury bills, has not been substantially altered. The SBP appears to be lending money to the government against securities, which it then offloads in the market. Although the potential inflationary impact of such government borrowings

\footnotetext{
${ }^{7}$ Although the rate is being forced through the State bank's intervention and its statutory liquidity requirements.
} 
becomes sterilized, the legal and practical autonomy of the SBP to apply its monetary management policies independently is compromised ${ }^{8}$.

It is also interesting to note that the State Bank's prudential regulations with respect to capital adequacy requirements for commercial banks have also reinforced and strengthened the role of the banks in holding government securities. All commercial banks are required to maintain a minimum capital to total risk-weighted assets ratio of $8 \%$. Resultantly, along with having to bear the cost of funds for holding government securities, banks are also required to carry the burden of an additional charge on their activities, which in turn depends upon the categories of assets held in accordance with the risk-weights assigned to each. Presently, the risk weights assumed are zero for investments in government securities and $100 \%$ for practically all categories of loans including those to the most credit worthy corporations and businesses; even the balances held with scheduled banks are assigned a risk-weightage of $20 \%$. With this difference in relative capital costs owing to these risk weights, the manner in which the capital adequacy norms are being applied has also created an incentive for banks in favor of investments in government guaranteed securities. In other words, the large sums invested by the banks in government paper are simply the natural outcome of these policies.

The author is aware that the State Bank is moving towards a refinement of these norms. However, even if these norms are changed, as they must be, it does not follow that when the commercial banks reduce their investment in government securities they will necessarily increase their loan portfolio at the same pace. As other financial institutions pick up these securities there would be a flow of household savings to them, resulting in a shrinking in the deposit base of banks with, perhaps, only a marginal increase in the total value of loans and advances made by them.

While some indicators, especially those pertaining to the availability of different products, efficiency and customer satisfaction have improved, other features depict less than satisfactory development. For instance, the money $\left(\mathrm{M}_{2}\right)$ to GDP ratio, which is supposed to signify financial deepening, has risen by just 4 percentage points, from $40 \%$ to $44 \%$ between 1985 and

\footnotetext{
${ }^{8}$ In India there is an agreement between the government and the Reserve bank of India that there will be no automatic replenishment as a result of which the central bank has acquired a semblance of independence.

9 The State Bank also has to sterilize large remittance inflows selling government securities in the absence of other paper for such activities. Thus the banks end up holding more government securities than what they would have if they had simply followed the requirements of the Prudential Regulations.
} 
2006 (suggesting that a major part of the economy is still non-monetized). It is not clear how much of this increase can be attributed to the reforms. Similarly, although deposits as a percentage of GDP have declined from $42.4 \%$ in 1997 to under $39 \%$ in 2006 this is largely because of the GDP rebasing effect. In comparison with the ratio for 2002 it has increased by 4 percentage points ${ }^{10}$.

To eliminate the monetary overhang of the previous six years and to curb demand, the SBP has been following a tighter monetary policy in the last two years (only in FY06 was the growth in broad money less than the nominal growth in the GDP) to curb demand. The banking system which was flushed with funds provided consumer finance liberally resulting in a further increase in money supply. This contributed to the fuelling of inflation (Figure 1) ${ }^{11}$ and forced the SBP to intervene through open market operations to squeeze money supply, although it did so with an inordinate delay. This strong monetary growth reflected largely in the abrupt increase in private sector credit, has sharply raised the general price level and prices of assets - land and equities.

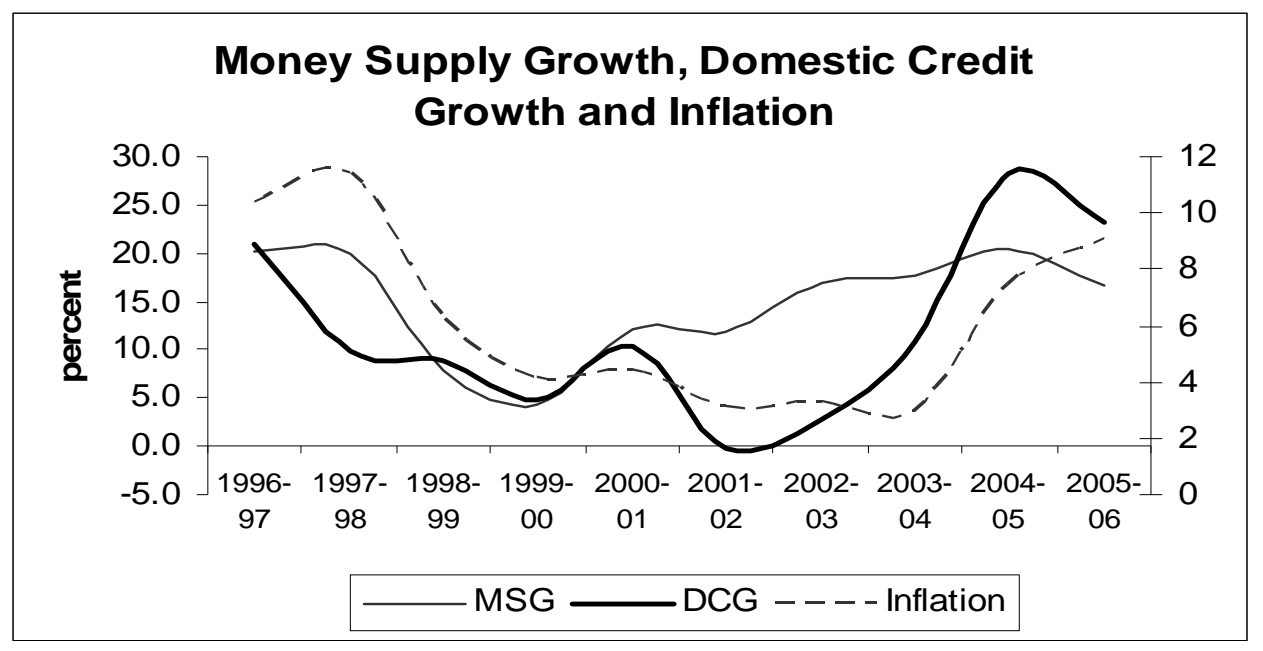

Figure 1: (right hand axis is for inflation and the left hand axis is for MSG and DCG)

To curb the stubbornly high inflation through a tighter monetary policy, the SBP raised the Reserve Requirements of banks from 5\% to $7 \%$

\footnotetext{
10 The low deposit to GDP ratio also raises questions about the efficiency of the banking system and the level of transaction costs that could be serving as a disincentive to the use and growth of the banking sector.

${ }^{11}$ I am grateful to Wasim Shahid of PIDE for preparing all the graphs used in this report.
} 
and the Statutory Liquidity Requirement on time and demand liabilities from $15 \%$ to $18 \%$ and the discount rate by 50 basis points, which while achieving the objective of a tighter monetary policy also made government borrowing cheaper than it might have been otherwise if only the discount rate had been raised. Presently, however, real interest rates on deposits are negative (the high rate of inflation keeping them negative) which, following the recent decision to permit institutions to invest in NSS instruments, is likely to encourage disintermediation, thereby forcing banks to compete for deposits by raising rates, especially for the longer tenor ones. Interestingly, the spread between the average deposit and lending rates continues to be high, having widened since the huge inflow of remittances and the notable growth in the economy, reflecting poorly on the efficiency and competitive environment in the banking sector.

In conclusion, however, it could be argued that in view of some of the trade-offs there is admittedly a need to strike a delicate balance, but only in the short-term, between the excessive tightening for demand management reasons and the momentum in economic growth. However, the question remains if these should be the concerns of the State Bank or should it merely focus on controlling monetary growth to restrain inflation, since empirical research has shown that low and stable inflation is conducive to economic growth, partly by ensuring that the expected rate of inflation of the general price level ceases to be a factor in business decisions ${ }^{12}$.

\section{Lack of Clarity on Objectives of Monetary Policy ${ }^{13}$}

A conundrum is the lack of clarity on the objectives of the present monetary policy. In the absence of the clarity of signals one should be excused from assuming that the State Bank is still trying to keep interest rates low as well as maintain, if not fix, the exchange rate, although basic economics inform us that you can cannot fix both simultaneously over a long stretch of time.

In other jurisdictions the performance of the central bank is judged by its success in controlling inflation. In Pakistan, the State Bank's previous leadership stoutly defended its monetary management aimed at pump priming of the economy resulting in inflation almost reaching double digits. It justified adopting an accommodating monetary policy that stimulated economic growth by keeping interest rates lower than the rate of inflation

\footnotetext{
${ }^{8}$ See Feldstein (1997), Goldstein (1995), and Mishkin (1997).

13 This section of the paper has benefited enormously from discussions with Dr. Nadeemul-Haque.
} 
(especially hurting depositors in the process) and did not use the capital inflows from abroad to retire expensive debt. The pursuit of this strategy and a monetary policy that was working at cross purposes, however, compromised its role as an independent agent mandated to keep inflation in check through interest rate adjustment.

Loose monetary policy, partly owing to the fiscal dominance in influencing this policy (see below) has fuelled the rate of inflation as well as the recent widening of the trade deficit. Simple, well-known, economic propositions inform us that monetary expansion or contraction leads to an increase or decrease respectively of aggregate demand which in turn directly impacts on import demand. In other words, monetary contraction will reduce overall demand and import demand and facilitate the trimming of the trade deficit. In most cases monetary tightening does not affect exports since these normally respond to external demand. Contrary to claims that monetary contraction will raise interest rates and adversely affect export competitiveness if monetary tightening lowers the rate of inflation and thereby the cost of production, exports could actually increase. Therefore, monetary contraction should be the appropriate policy to reduce the trade deficit.

A contractionary monetary policy that reduces aggregate demand will tend to depress growth. But this is a price that will have to be paid to return to macroeconomic stability. However, the likelihood of its recessionary impact tends to get overstated. Empirical studies have shown that the interest elasticity of investment and GDP growth may not be that strong; it is issues such as poor governance, policy uncertainty and slow structural reforms that pose more fundamental problems. Even the Pakistani case shows lack of any significant increase in investment despite interest rates being negative in real terms for a significant period.

Allowing monetary policy to inflate the economy has long-term consequences as economic actors factor in inflationary expectations into their actions to address the uncertainty induced by decision makers. The State Bank has to earn for itself the credibility of a responsible monetary manager, which it lost through the footloose expansion that it had permitted earlier.

The State Bank can use a combination of interest and exchange rates to manage aggregate demand. The exchange rate policy facilitates switching of demand from foreign goods to domestic goods, with an undervaluation making domestic goods cheaper relative to foreign goods, thereby improving the external balance. 
Depreciation will also reduce the domestic cost of production and have a favorable impact on the trade balance. Hence to deal with a trade problem, depreciation is always a real policy choice. In any case, depreciation becomes necessary after a period of monetary expansion. During a longish period of monetary expansion, domestic inflation grows at a faster pace than inflation among our trading partners and competitors. This inflation differential will eventually have to be bridged by currency depreciation. Of course, a depreciation in the exchange rate will have an impact on the rate on inflation to the extent of the share of traded goods in the economy.

The rupee is currently overvalued. The standard, and hackneyed, argument of policy makers that the price of the rupee is no longer determined by the government but by the market and since capital inflows, most of which are non-debt creating in nature (foreign remittances, privatization receipts, donor grants and direct foreign investment) are largely financing the deficit on the external trade account, the value of the rupee continues to be steady. Even if their contention that the market is determining the value of the rupee were to be accepted, the question is whether allowing foreign exchange inflows (most of which are non-secure in nature) to keep the value of the rupee artificially higher (while also requiring monetary management to be more stringent) than it would be otherwise is a good strategy for the profitability of our exports, especially considering that our domestic rate of inflation is significantly higher than that of our trading partners and competitors. The lowering of the profitability rates and levels in the export and modern sectors of the economy is acting as a disincentive to invest in these sectors. Hence the movement into other activities like real estate and the stock exchanges, and to some extent in manufacturing for the domestic market in the more protected industries.

If China were to follow this advice, the value of the Yuan would be appreciating (since it has a huge trade surplus with the rest of the world and is also experiencing large capital inflows). China, by not choosing to sharply revalue its currency upwards and maintaining a highly competitive currency, has not only made it exceedingly difficult for the competitiveness of our exports, but has also kept profitability and investment high in its exporting industries. So, who is suffering on account of this reality? If, when we find our strategy unsustainable (especially when there are no privatization proceeds to finance part of the trade deficit), we decide to adjust the value of the rupee, some of our export markets would have been lost, having been captured by others, and our re-entry in these markets is bound to be awkward, if not impossible. 
The responsibility of the State Bank is to develop a credible monetary policy that neither inflates nor deflates the economy. This requires patient research and handling. Without a credible monetary policy, which lowers inflationary expectations, we could be supporting a vicious circle of exchange depreciation and inflation. In other words, a devaluation of the rupee will also have to be backed by a reasonably tight monetary policy to deal with a trade deficit/inflation problem.

In general, interest rates move slowly in response to changes in liquidity. According to the SBP Annual Review of the Economy, 2005/6 recent research on transmission lags suggests that monetary tightening impacts significantly on inflationary pressures over a 28 month period. If interest rates are to become a policy variable then the government should become neutral to them. And it will become neutral only if it reduces its borrowings considerably. This means that the fiscal deficit must come down for credit markets to function smoothly.

\section{Fiscal Policy}

As mentioned above in the introduction, the overall fiscal deficit has been rising ${ }^{14}$ (Figure 2). This expansionary fiscal stance of the government, given weak domestic resource mobilization, has not been consistent with the SBP's tight demand management posture and has induced risks through the stoking of inflationary pressures and the stress it brings to bear on interest rates for managing demand. The degree of impact also depends upon the manner in which the government finances its fiscal deficit - its present monetization through heavy borrowings from the SBP directly rather than from the financial system.

\footnotetext{
${ }^{14}$ However, to give the government its due, part of the borrowing was prompted by the expenditure requirements for earthquake relief and rehabilitation operations, which have contributed just under $1 \%$ of the GDP to the fiscal deficit
} 


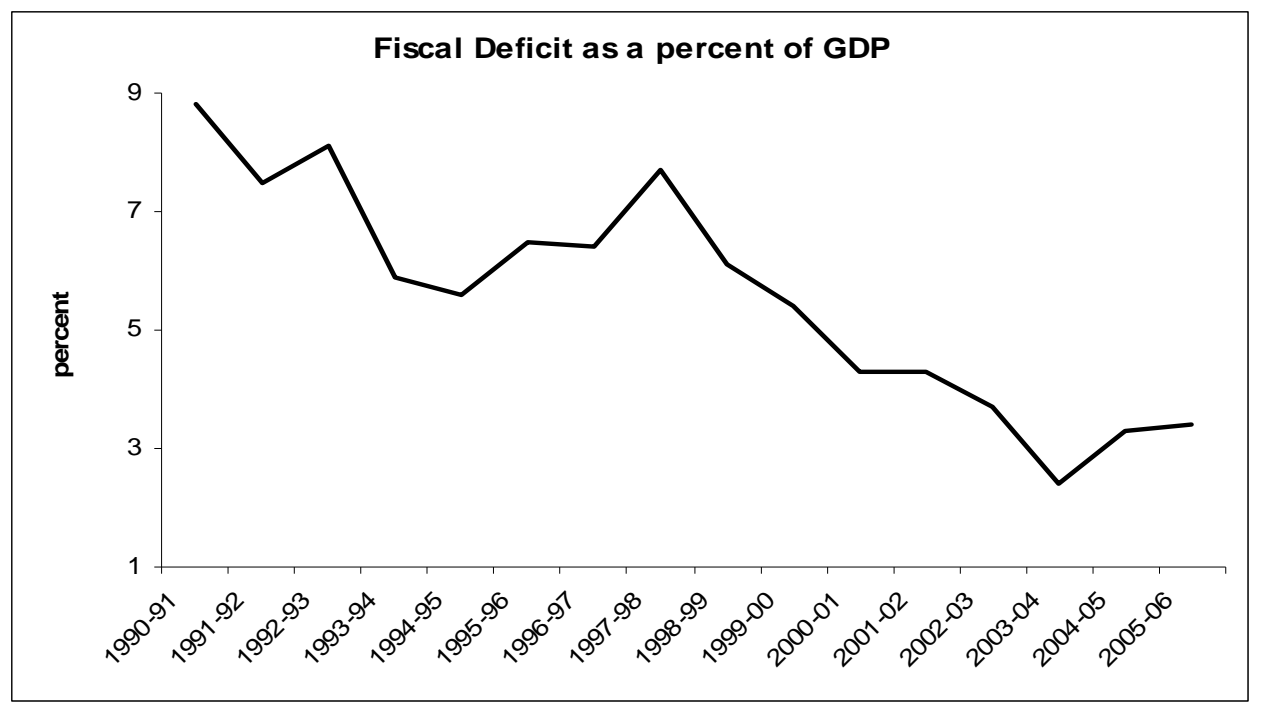

Figure 2:

In my view there has been an overemphasis on the revenue side of the equation and little has been said or examined about the level and efficiency of government expenditures, with good governance associated with transparency and accountability as the key drivers for improving the productivity and efficiency of government expenditures.

There have been no significant reforms in government spending and a huge problem lies unaddressed on the expenditure side. It is a big black hole and a great deal of adjustment needs to be made both in terms of the structure and the efficiency of public expenditures, particularly with respect to defence related expenditures; while absorbing a third of government revenues $^{15}$, they are characterized by complete lack of transparency (it being reflected as a single line item in the budget). Despite our nuclear deterrent and the peace overtures to India there is no let up on defence expenditures. The current strategy is seemingly adamant that defence policy and its effectiveness cannot be compromised, whatever the costs. Confronted with such a hypothesis, it is difficult to have a meaningful debate even when our distorted priorities have resulted in 6 soldiers per doctor and 1 teacher for every soldier.

${ }^{15}$ The expenditure is higher because military pensions, which are in excess of Rs. 30 billion per annum, are under civilian pensions, and expenditure supported by US military aid of more than US $\$ 700$ million per annum for the fight against terrorism has also not been factored in. 
The composition of public expenditure has also become unbalanced because of inflexible expenditure commitments. Resultantly, much of the fiscal space created by the recent rescheduling and re-profiling of debt has been absorbed by the rigidities in non-development expenditures particularly salaries of a bloated civil service with few relevant skills required to manage a modern economy in a highly globalized world.

This author is of the opinion that there is a need to downsize the government by means of its steady withdrawal, especially that of the federal government, from many of the functional responsibilities that it has taken upon itself. The functions so relinquished should either be organized by the private sector or should be hived off to lower formations of government by reducing the multiplicity of agencies engaged in similar activities. In particular, the government continues to devote a disproportionate share of its resources to activities that would be more efficiently provided by the private sector. All this, combined with endemic governance issues, has resulted in accumulated losses of public sector enterprises crossing Rs. 250 billion with an annual addition in excess of $1 \%$ of $\mathrm{GDP}^{16}$. Although some public sector enterprises and the CBR have been performing relatively better than other public sector entities, the woes of PIA, WAPDA, Railways, KESC (even after privatization based on written agreements with the private owner and operator) etc. continue to dog the contribution of the public sector to national savings, which are adding to the rapid growth in the quasi-fiscal deficit. In other words, there are hidden deficits because of losses of public sector enterprises that have not been accounted for in the fiscal deficit. Such "creative accounting" has resulted in lower fiscal deficits. The fiscal deficit would also be higher if the desirable amounts of funding were to be made available for improving service delivery in the social sectors.

Another persistent issue concerns the low efficiency of public sector expenditures in terms of the higher costs per unit of public sector construction projects because of corruption, poor competence of the government and other leakages. There is evidence that it would cost the government at least $50 \%$ less to fund schooling through privately managed institutions (and that too of better quality) instead of delivering education through the publicly run schools. ${ }^{17}$

\footnotetext{
${ }^{16}$ These are estimates obtained from various reliable sources since the government does not report the financial results of public sector corporations regularly reflecting poorly on its claims of transparency.

${ }^{17}$ The Punjab Education Foundation is funding private schools by providing Rs.300 per child enrolled (compared with more than Rs. 450 per child per month that it costs the
} 
To check the growth in the fiscal deficit and the level of debt, the GoP has adopted legal ceilings (as a percentage of GDP) for advances to the government through the Fiscal Responsibility and Debt Limitation Act. However, the legislation aimed at reducing the fiscal deficit has several weaknesses. Some of these are discussed below.

Whereas it proposes to pare the deficit on the revenue account, such a reduction and the lowering of the debt to GDP ratio could be achieved by different compositions of budgetary expenditures with sharply different outcomes. For instance, the same level of revenue deficit can be realized by cutting back much needed expenditure on the repairs and maintenance of installed infrastructure (as is happening in Sindh which claims that its overdraft with the State Bank has turned into a positive cash balance). This lowering of expenditure, and the resulting deferred maintenance, would eventually get reflected as development projects in future years- a strategy that successive governments have been guilty of adopting in the past. Such an outcome, obviously, cannot be the objective of the proposed enactment.

While the government has been able to lower the debt to GDP ratio to 60\%, a target set for 2013 under the Fiscal Responsibility Act, and has also succeeded in sharply bringing down the ratio of interest payments to GDP from $6.9 \%$ in FY00 to just over 3\% in FY06, the reduction can be achieved by the government cutting back on priority investment expenditures and on social safety nets (as is the case today, being barely $0.3 \%$ of the GDP) rather than raise taxes or rationalize user charges (as has been happening in recent years), with all its implications for economic activity in general. There would be little economic justification for restructuring government investment that could have a high social return, since there are externalities of some investments that need not contribute directly to government revenues.

Furthermore, although the stock of debt to GDP ratio has fallen dramatically, the debt profile has not improved to the extent that it should have, given that the financial system was flushed with funds, suggesting that the Federal Government has managed its debt poorly. When it could have borrowed long at low interest rates, for a while it stopped issuing 7 to 10 year Pakistan Investment Bonds. It chose instead to offload 6 month T-bills at $2 \%$ or so when inflation had begun to climb and there was every sign that the interest rate structure would change and rates would rise sharply.

government to educate a child in a government run institution) and running half-yearly quality assurance tests to ensure that assisted schools are providing a minimum acceptable level of education in terms of student learning outcomes. 
This flawed strategy cost the government and the tax payers dearly as the debt profile became skewed in favor of short-term debt. The opportunity cost of this poor financial management has been massive - it could be as much as Rs.100 billion over the next 10 years. While the government would, and should, have raised more long-term relatively cheap debt, it took the bizarre decision to discontinue issuing bonds of longer term maturities and relied more on short-term bonds ${ }^{18}$.

Moreover, there is also a need to distinguish between the structural and cyclical components of the deficit, a need to improve the cost effectiveness of government expenditures and to raise the tax to GDP ratio over time. Without a stipulation separating the structural from the cyclical components of a deficit, the present government would not have been able to undertake the kind of capital restructuring of KESC, WAPDA and PIA that have been, or will be, forced upon it, which, in the past pushed the fiscal deficit beyond the targeted level.

Treasury bills and other government bonds held by the State Bank essentially serve the purposes of a monetary policy. This holding may increase or decrease based on open market operations conducted by the $\mathrm{SBP}^{19}$. Since one of the implicit aims of the proposed legislation is to grant greater independence to the SBP to conduct its monetary policy, then the SBP's holdings of such government securities should be excluded from the purview of this legislation. This is because these bonds would not, in the true sense of the term, constitute a part of the government's debt, since the SBP is in itself a part of the government and if a consolidated balance sheet were to be prepared, this debt would be cancelled as a contra item. This writer would, therefore, propose that, in keeping with the spirit of the Act, only that part of government debt held by households, companies, and financial intermediaries/institutions should be regarded as public debt, since the servicing of only this debt would generate a flow of funds (in the form of payments) from the government to the private sector of the economy.

\footnotetext{
${ }^{18}$ As a result of poor monetary and debt management a huge opportunity has also been lost to develop a market for low cost housing finance, hitting the less affluent segments of society, already suffering from the ravages of inflation, even more.

${ }^{19}$ Ideally this legislation should also prevent the government (on the basis of a phased program) from accessing the SBP for financing. Under the latter arrangement, the SBP would only function as an agent of the government in financial markets.
} 


\section{Revenue Mobilization and Taxation Structure}

Largely owing to the recent rebasing of Pakistan's national income, the inclusion of new sectors to reflect the changing structure of the economy and the revision in the contribution of some sectors to this emerging pattern, Pakistan's revenue performance now seems to be out of line with the tax efforts of other countries with similar per capita GDPs. An IMF cross-country comparison shows that:

a) Pakistan's revenues from taxation are still hovering at under $11 \%$ of GDP (Figure 3), the lowest among regional countries, being at least 2 percentage points lower than the average for its South Asian counterparts Bangladesh, India, Nepal and Sri Lanka; and

b) The tax to GDP ratios of other comparator economies (such as Bolivia, Egypt, Indonesia, etc.) is 7 to 8 percentage points higher.

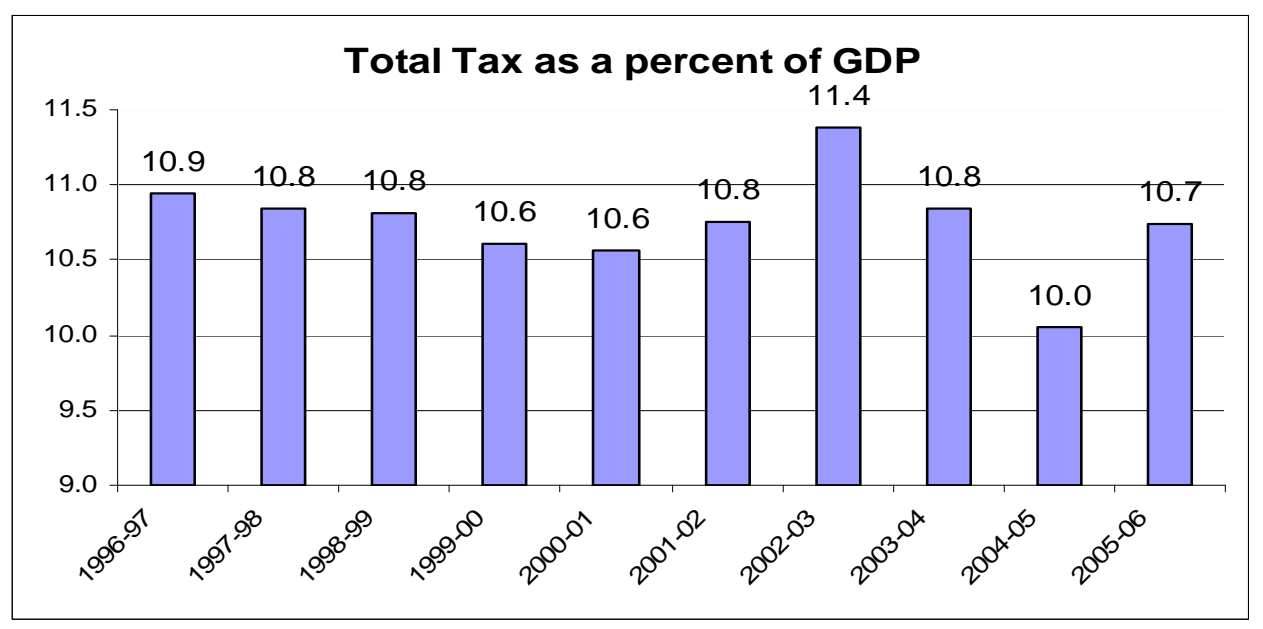

Figure 3:

A positive feature has been the reduced reliance on revenues from the taxation of foreign trade. However, since customs duty reductions to improve efficiency in production and trade were introduced at a rate faster than the corresponding reforms in GST and direct income tax, there was a loss of revenues as increased revenue from reforms in GST and direct taxes did not materialize at the projected pace. Resultantly, so far we have a narrow and concentrated tax base, almost half of the tax revenues are contributed by imports, and domestic taxes to GDP ratio continue to be below 5\%. Even in the latter case just 6 items, particularly 
telecommunications, fuel and energy, motor vehicles and iron and steel, account for more than half of indirect tax collection.

While tax revenues have increased sharply in rupee terms in recent years, this growth has barely kept pace with the growth in the economy. The tax to GDP ratio has remained flat, if not having declined, partly because of continued tax reliefs (e.g of agriculture from income tax and of freight and services such as railway fares, professionals - lawyers, doctors, accountants, architects, engineers and tax and other consultants - from GST) and additional exemptions. The buoyancy in tax revenues has been substandard ${ }^{20}$, reflecting on the tax structure riddled with exemptions and administrative weaknesses in the collection machinery and compliance systems and procedures- the latter partly owing to express government policy to reduce the cost of doing business. In my opinion, the mobilization of tax revenues is also difficult because of the lack of faith of people that the government will honor its social contract to deliver basic services and utilize resources judiciously and prudently following generally accepted principles of propriety (as should be expected from a trustee of public funds) and not used to finance luxuries and junkets of the rulers and their cronies.

However, despite the narrow base, one key factor underlying the high cost of doing business in Pakistan is the system of taxes. Not only is the system characterized by both multiple taxation and agencies (e.g. GST on Services, professional tax by provinces and professional fees by district governments) and high rates of corporate and, until recently, personal income taxes, taxpayers have to contend with complex rules, procedures and mechanisms employed to implement tax policies, although much has improved since the institution of the new tax laws and the introduction of a universal self-assessment scheme.

As mentioned above, although we have a lower tax to GDP ratio, our income tax rates are, at $35 \%$, higher than those of comparator countries and some OECD and ASEAN countries- where they range from $20 \%$ to $30 \%$ (although personal income tax rates are higher in Europe), indicating the need to broaden the narrow tax base by eliminating exemptions, lowering some of the tax rates and related charges (e.g. commercialization rates) and revising the tariff structures, and ensuring better documentation of transactions and improving administrative efficiencies. As illustrations of

${ }^{20}$ According to the SBP, although the tax buoyancy has improved from $0.8 \%$ in FY05 to $1.2 \%$ in FY06 it is still low compared with the average of $1.33 \%$ for other economies in the region. 
tariff structure revisions, we need to withdraw the exemption for capital gains on the trading of shares of listed companies ${ }^{21}$, extend the scope of GST on services ${ }^{22}$, make rental income taxable in the same way as income from other sources ${ }^{23}$, consider taxing gifts and introducing an inheritance tax and lowering the high import tariffs to protect the assemblers of motor cars and motorcycles which results in these enterprises collecting, as corporate profits, what would have been tax revenues.

Moreover, countries with tax to GDP ratios of $20 \%$ and above, unlike Pakistan, run and manage social welfare systems for their populations; the mismatch is stark in the visible returns that developed societies and citizens obtain from the state on the taxes they pay.

Thirdly is the issue of multiple taxes, which raises the effective rate of tax even further. For instance, the manufacturing sector pays an additional $5 \%$ tax on profit as a contribution to the Workers Profit Participation Fund, a $2 \%$ tax on account of Workers Welfare Fund, a 5\% levy on the wage bill for EOBI, a $7 \%$ levy for social security, one month's salary as bonus for workers, excise duty (in the case of some industries), an Education Cess of Rs.100 per worker, a provincial professional tax and a district government professional fee over and above the GST on its products/services.

Furthermore, bonus shares/stock dividends and realized capital gains from trading in shares, debt instruments and property related transactions (unless these represent business income) continue to be exempt from tax, discouraging investment in the productive and real sectors all of which are

${ }^{21}$ Just in the last 2 years, the stock market index has jumped from around 6,000 to over 11,000 this month (April/May 2007) with market capitalization shooting up from Rs.1.7 trillion to Rs.3 trillion indicating that a capital gain of more than a trillion rupees accruing to holders of listed shares escaped taxation because of a specific tax exemption for capital gains arising from trading in listed securities.

${ }^{22}$ Under the Constitution, the GST on Services is a provincial subject and the Federal Government is reluctant to extend the scope of this tax to include in its ambit powerful lobbies like lawyers and other professionals and take political flak for no return, as the entire proceeds, except for a $2 \%$ percent collection charge would go to the provinces. To improve the incentive for the Federal Government to levy this tax which could contribute significantly to revenues (since services now have the largest share in the GDP) it is time to amend the Constitution accordingly so that the GST on Services becomes a part of the divisible pool to be shared in the same ratio as other taxes under the NFC Award.

${ }^{23}$ A withholding tax at 5\% represents full and final settlement of the tax liability from rental income instead of it being treated as a tax credit in determining the gross taxable income and accordingly the tax liability of the taxpayer. 
taxable. This discriminatory fiscal treatment creates distortions by introducing a bias in favor of investment in certain instruments and sectors.

Therefore, the existing structure should be replaced with one that has lower rates - at most $30 \%$ for the corporate sector - but with very few exceptions (to check discretion), remembering that the principle of horizontal equity is violated through both exemptions and defective definitions of 'taxable income'. To this end, therefore, the personal income tax structure can be further simplified by having just a handful of rates (ideally just two as proposed by the Kelkar Commission in India) to minimize the impact of 'bracket creep' as tax payers enter higher marginal tax brackets because of the inflationary increase in incomes (unless the tax slabs are also indexed). The structure should link the progression in tax rates with the standard exemption limit of income, which should be fixed at a level that would ensure a balance being struck between revenue considerations and the capability of the administrative machinery to exploit the full potential of the revenue base. Personal income tax should, therefore, be built around at most three rates (compared with more than 15 slabs today) with a higher exemption threshold, while ensuring that all realized capital gains and receipts as wages and salaries, benefits in kind (perquisites), interests, dividends, income from agricultural activities and rent earned on property form part of the base to be taxed.

In the budget for this year (FY07), the rates of income tax were reduced after the inclusion of perquisites in calculating taxable income. While it was a step in the right direction, the main beneficiaries are again the higher paid executives. Their tax liabilities have actually declined substantially, by as much as $23 \%$, from the tax reliefs announced, since under the existing tax regime limits on the tax exemptions on salary related allowances were already operational and hence being taxed.

There is also a need for more effective audit systems rather than dependence on voluntary compliance, in view of the high degree of tax evasion, corruption and filing of fake claims for GST refunds in the country.

Through taxation, the state reduces the spending capacity of its citizens. Therefore, any effort to raise tax revenues evokes criticism and protest, even resistance. What is less important is the inherent merit of any proposal. It is its voter, and media, acceptability which carries more weight, since tax reform cannot benefit all citizens. The more vocal the losers the less likely will it be for a proposal to be accepted unless the overall package distributes the burden fairly and equitably. The government has lost much of the moral high ground for simplifying the system because of its failure to 
understand the imperatives of the political economy of tax reform. A good example of the weakness in the strategy is the decision to continue to treat government employees as a special group. The tax exemption that they continue to enjoy on their allowances results in the loss of moral legitimacy of the underlying conceptual framework to correct the distortions and the potential for abuse (their perquisites being exempted from tax on the plea that their salaries were not market driven). This matter should either be treated separately or the decision not to tax the perquisites of government employees should be explained in a more transparent manner. A better policy would be to monetize the entitlement of government employees to perquisites and benefits.

Since the rules for allowing tax deductions for certain expenses are much more stringent when it comes to salary incomes than for incomes from other sources, especially with regard to verification issues, a better alternative is to raise the standard/threshold income to be exempted from taxation. There is also a desperate need to bring some conceptual clarity between the deductions or exemptions that would be allowed for reasons of horizontal equity or would be treated as critical components of an incentive framework. An example of the latter case would be the deduction for medical insurance or medical treatment. These contributions should continue to be allowed since it is a cost of being healthy and fit so as to be able to earn - i.e., a cost to earn or to maintain human capital. Medical expenses are permitted up to certain specified limits in Italy, Japan, Netherlands, USA and Malaysia.

Moreover, much more needs to be done to enhance transparency and reduce taxpayer compliance costs by making judgments of income tax tribunals and higher courts more freely available on the internet, thereby reducing the role of the intermediaries, tax practitioners, who charge clients for what should be public information.

Moving on to another major revenue instrument, the customs/ import tariff, its structure remains complex and unwieldy even after several efforts to reform it since 1991. In almost every chapter there are multiple rates, several exemptions and several conditions and lists spread over hundred of pages of the book on tariff code/customs valuation. Then there are sector-specific or use-based exemptions, for which to avail of, necessitate queries of appraisers for literature and certificates, thereby not just providing an opportunity for exercising discretion but also slowing down the clearance of goods. 
On the face of it, the division of all goods into three categories (raw materials, intermediate and finished goods) that has been made for developing the customs tariff looks good in theory. It is, however, difficult to implement in practice. The concept that raw materials should be liable for a lower rate is impossible to implement practically since a large proportion of goods, e.g., chemicals, are both finished goods as well as raw materials. A similar problem arises when it comes to identifying intermediate goods that supposedly attract a lower rate than finished goods. In addition to the problem of dual use, it is also difficult to draw a line between the final, finished, consumer good and its sub-assemblies. A better alternative would be One - Chapter One - rate that would address considerations of revenue, the need for giving only reasonable protection ${ }^{24}$ to domestic industry and the need for simplification.

A few easily identifiable consumer goods such as air conditioners, expensive motor car brands, tobacco, liquor, generally viewed as goods for conspicuous consumption, could also be identified separately and made liable for a higher rate.

The import duty exemptions should be phased out quickly. Unless exemptions are withdrawn it will be difficult to achieve the objectives of simplification and the speedy clearance of imports. Only life-saving goods, goods of strategic interest and security or those for charitable purposes or those satisfying international obligations should be exempt from import duties. Otherwise, relief should be granted as a support through a budgetary allocation. This will have the added advantage of being transparent, being open and subject to parliamentary and public scrutiny. However, the free flow of goods should be permitted, with a focus on intelligence gathering and valuation checks to deter import duty evasion.

Finally, lest we forget, a computerized system of customs valuation can be user-friendly only when the tariff is computer-friendly. Automation alone cannot improve matters unless the tariff structures are decongested of numerous exemptions, conditions and lists.

Admittedly however, the reality is that there are no quick fixes. Exercises to simplify tax laws and ensure effective enforcement can take several years, as the experience of even developed countries shows - for instance, it took Canada 10 years to implement the proposals of the Carter Commission.

${ }^{24}$ Rather than the high levels of protection provided to assemblers of motorcycles and motor cars that enable them to pocket, as private profits, what would have been tax revenues from a more rational import tariff structure. 


\section{Conclusions}

The primary objective of the State Bank should be the maintenance of price stability as a major policy contribution to sustained economic growth. Hence, tighter monetary and fiscal policies (especially since the primary surplus of $1.7 \%$ of GDP in FY04 has become a deficit of around $0.5 \%$ of GDP in FY06) will be required over the medium-term. However, the domestic and external debt situation, despite the high debt to revenue and debt to export ratios (essentially because of low revenues and exports), will remain favorable, as will the interest rate and exchange rate risk (again despite the rupee being overvalued, by $10 \%$ according to the IMF and around $18 \%$ by the World Bank compared with the official admission of a misalignment by only $2-4 \%$ ). The State Bank should clearly spell out its monetary policy and related objectives today to achieve its inflation target of around $5 \%$ over the next 8-12 months.

There is a need to not only to raise public savings through higher revenues and better expenditure control, there is also a need to diversify sources of borrowing, in particular, as argued above, to improve the mix of short-term and long-term borrowings. Moreover, unfortunately even when it decided to resort to long-term non-bank borrowings, the government chose to do so through NSS instruments by allowing institutional investors to opt for NSS, reversing an earlier decision that had closed this option for them. This has adversely affected the development of a capital market for longterm debt, critically required to evolve a robust housing finance system and draw private sector investment into long gestation infrastructure projects.

In conclusion I would like to emphasize that apart from macroeconomic stability, governance mechanisms, institutions and the institutional environment such as the rule of law, societal norms and values, work ethics, enforcement and related costs of property and contractual rights are important for facilitating economic growth and influencing economic efficiency. 


\begin{tabular}{|c|c|c|c|c|c|}
\hline \multirow{2}{*}{\multicolumn{2}{|c|}{$\begin{array}{ll}\text { Ratio to GDP } \\
\text { FY06 }\end{array}$}} & \multirow{2}{*}{\multicolumn{3}{|c|}{ FY02 }} & \\
\hline & & & & & \\
\hline \multicolumn{2}{|l|}{ Investment } & \multicolumn{2}{|c|}{$16.8 \%$} & & $20 \%$ \\
\hline \multicolumn{2}{|l|}{ National savings } & \multicolumn{2}{|c|}{$18.6 \%$} & & $16.1 \%$ \\
\hline \multicolumn{2}{|l|}{ Domestic Savings } & \multicolumn{2}{|c|}{$17.0 \%$} & & $14.7 \%$ \\
\hline \multicolumn{2}{|l|}{ Tax Revenues } & \multicolumn{2}{|c|}{10.9} & & 10.5 \\
\hline \multicolumn{2}{|l|}{ Total Revenues } & \multicolumn{2}{|c|}{14.2} & & 14 \\
\hline \multicolumn{2}{|l|}{ Expenditure } & \multicolumn{2}{|c|}{18.5} & & 18.2 \\
\hline \multicolumn{2}{|c|}{ Development Expenditure } & \multicolumn{2}{|c|}{2.9} & & 4.2 \\
\hline \multicolumn{2}{|c|}{ Current Expenditure } & \multicolumn{2}{|c|}{15.9} & & 13.6 \\
\hline \multicolumn{2}{|l|}{ Overall Deficit } & \multicolumn{2}{|c|}{4.3} & & 4.2 \\
\hline Growth \% & FY02 & FY03 & FY04 & FY05 & FY06 \\
\hline Monetary (M2) & 15.4 & 18.0 & 19.6 & 19.3 & 15.2 \\
\hline Private Credit & 4.8 & 18.9 & 29.8 & 34.4 & 23.5 \\
\hline
\end{tabular}

Sources: IMF, December 2006 and State Bank Annual Report, 2005/06

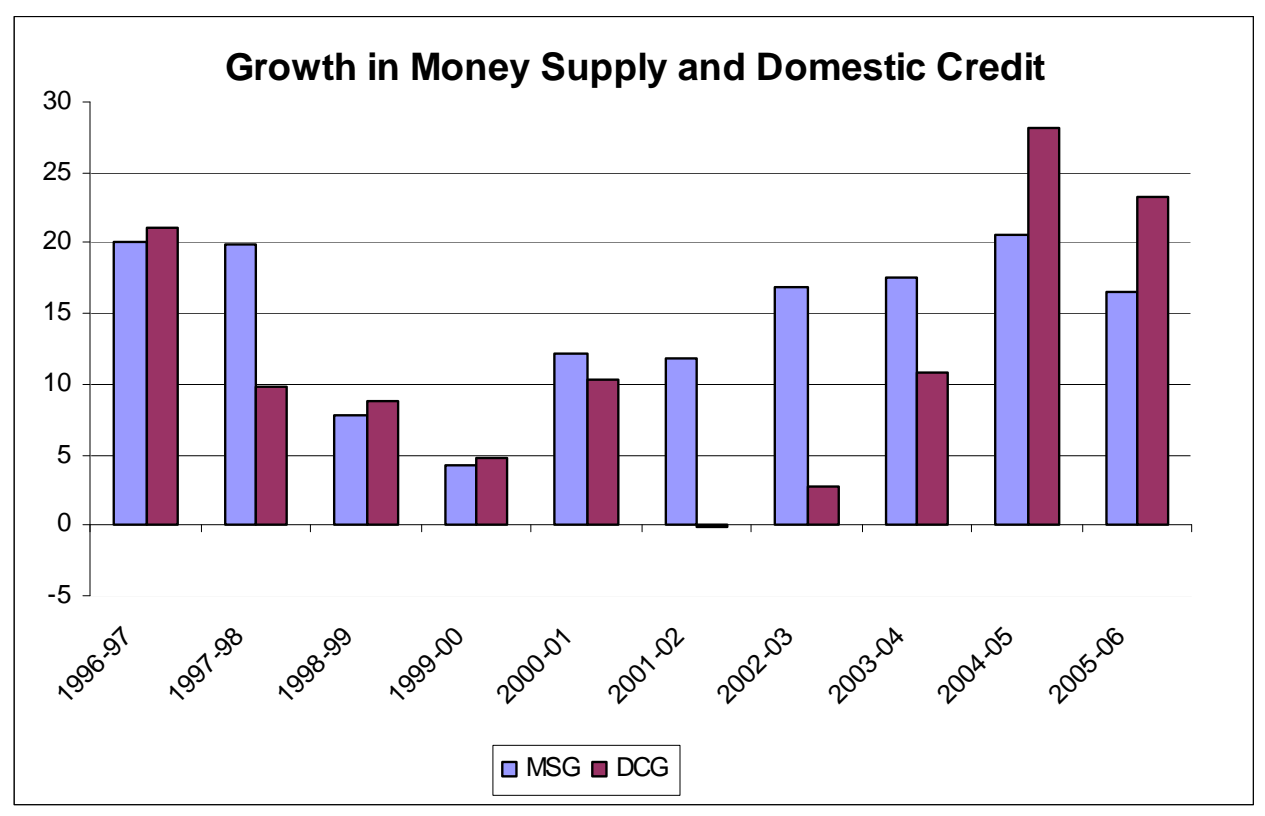




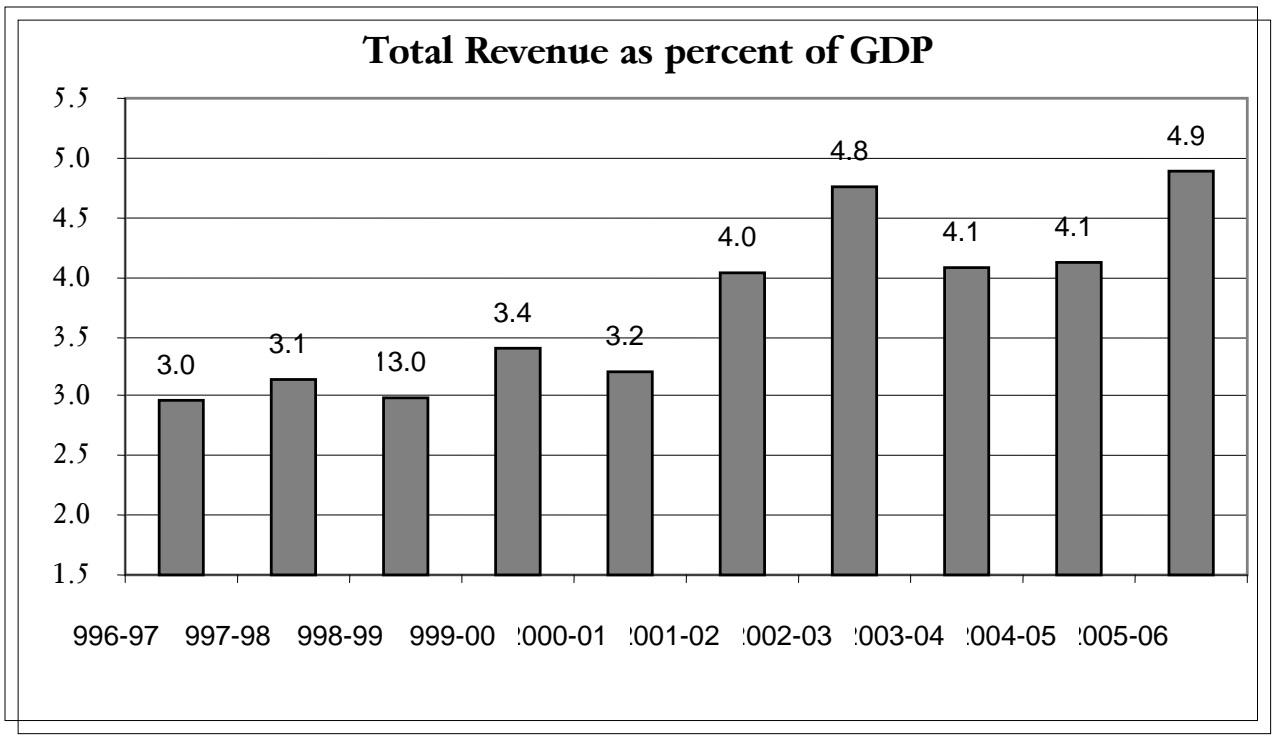




\section{References}

Feldstein, M, 1997. "The Cost and Benefits of Going from Low Inflation to Price Stability,” National Bureau of Economic Research paper 5469.

Goldstein, M., 1995. "Acquiring and Maintaining Credibility for Low inflation, The US Experience”, in L. Leiderman and Lars Svenensson (ed.) "Inflation Targets", Centre for Economic Policy Research, London.

Khan, Mohsin and Schimmelpfennig, Alex, 2006. Pakistan Development Review, 45(2): 185-202.

Mishkin, F., 1997. "Strategies for Controlling Inflation,” in P. Lowe (ed.), "Monetary Policy Inflation Targeting," Proceedings of a Conference, Reserve Bank of Australia, Sydney.

Qayyum, Abdu1, 2006. "Money, Inflation and Growth in Pakistan,” Pakistan Development Review, 45(2): 203-212.

State Bank of Pakistan, 2006. State Bank Annual Report, 2005/06. 